\title{
Correction: Understanding the Citizen Science Landscape for European Environmental Policy: An Assessment and Recommendations
}

Anne Turbé*, Jorge Barba ${ }^{\dagger}$, Maite Pelacho ${ }^{\dagger, \neq}$, Shailendra Mudgal§, Lucy D. Robinsonll, Fermin Serrano-Sanz ${ }^{\dagger}$, Francisco Sanz ${ }^{\dagger}$, Chrisa Tsinaraki ${ }^{\uparrow}$, Jose-Miguel Rubio** and Sven Schadeף

This article details a correction to the article: Turbé, A., Barba, J., Pelacho, M., Mugdal, S., Robinson, L.D., Serrano-Sanz, F., Sanz, F., Tsinaraki, C., Rubio, J.-M. and Schade, S., 2019. Understanding the Citizen Science Landscape for European Environmental Policy: An Assessment and Recommendations. Citizen Science: Theory and Practice, 4(1), p.34. DOI: http://doi.org/10.5334/cstp.239

\section{Correction}

After publication of Turbé et al. (2019) it was brought to light that the names of two co-authors were presented incorrectly. The authors would like to correct the appearance of the name Shailendra Mugdal to Shailendra Mudgal in the author list. They would also like to correct the appearance of the name Chrysa Tsinaraki to Chrisa Tsinaraki in the author list.

\section{Competing Interests}

The authors have no competing interests to declare.

\section{Reference}

Turbé, A, Barba, J, Pelacho, M, Mugdal, S, Robinson, LD, Serrano-Sanz, F, Sanz, F, Tsinaraki, C, Rubio, J-M and Schade, S. 2019. Understanding the Citizen Science Landscape for European Environmental Policy: An Assessment and Recommendations. Citizen Science: Theory and Practice, 4(1): 34. DOI: https://doi.org/10.5334/ cstp.239

\footnotetext{
Ecoscope, Haifa, IL

Ibercivis Foundation, ES

University of the Basque Country (UPV/EHU), ES

BIO Innovation Service, Paris, FR
}

\footnotetext{
Natural History Museum, Cromwell Road, London, GB

- European Commission - Joint Research Centre (JRC), Ispra, IT

** European Environment Agency (EEA), Copenhagen, DK

Corresponding author: Anne Turbé (aturbe@gmail.com)
} 
How to cite this article: Turbé, A, Barba, J, Pelacho, M, Mudgal, S, Robinson, LD, Serrano-Sanz, F, Sanz, F, Tsinaraki, C, Rubio, J-M and Schade, S. 2020. Correction: Understanding the Citizen Science Landscape for European Environmental Policy: An Assessment and Recommendations. Citizen Science: Theory and Practice, 5(1): 5, pp. 1-2. DOI: https://doi.org/10.5334/cstp.308

Submitted: 22 January 2020

Accepted: 22 January 2020

Published: 20 February 2020

Copyright: ( 2020 The Author(s). This is an open-access article distributed under the terms of the Creative Commons Attribution 4.0 International License (CC-BY 4.0), which permits unrestricted use, distribution, and reproduction in any medium, provided the original author and source are credited. See https://creativecommons.org/licenses/by/4.0/.

$\mathrm{u}[\mathrm{C}$ Citizen Science: Theory and Practice is a peer-reviewed open access journal published by $\quad$ OPEN ACCESS $\boldsymbol{\odot}$ Ubiquity Press. 